\title{
Sketsa Kebudayaan Lembaga Pendidikan Islam
}

\author{
Hendro Widodo \\ Universitas Ahmad Dahlan Yogyakarta \\ e-mail: hwpgsd1960@gmail.com
}

\begin{abstract}
The development of pesantren, schools and madrasah is a form of culture. They have dynamism in the society development. Pesantren, schools, and madrasah are also a manifestation of the lives of people or groups of people in the educational environment. The development of pesantren, school and madrasah as a unity of the development of educational institutions in Indonesia are interconnected with each other, so the cultural development of the three educational institutions can be seen from the cultural model proposed by van Peursen, covering mythological, ontological and functional phases. This article reveal and explore the development of pesantren, schools, and madrasah in cultural reviews. The researcher used cultural theories of van Peursen and Auguste Comte.
\end{abstract}

Keywords: Pesantren, School, Madrasah, Culture 


\section{Pendahuluan}

Pendidikan memiliki suatu keunikan, di satu sisi merupakan bagian kebudayaan, namun di sisi lain merupakan bentuk proses pembudayaan yang sifatnya spesifik dan berkesinambungan. Hal ini sesuai dengan pandangan van Peursen yang memandang bahwa kebudayaan itu sebagai suatu proses pelajaran, suatu "learning process", yang terus menerus sifatnya (C.A. van Peursan, 1988:5).

Kebudayaan meliputi segala perbuatan manusia, termasuk pula kesenian, ilmu pengetahuan dan agama. Jadi, ruang lingkup kebudayaan sangat diperluas. Hal ini menunjukkan pergesesan isi konsep kebudayaan, bahwa kini kebudayaan dipandang sebagai sesuatu yang lebih dinamis, bukan sesuatu kaku atau statis. Dulu kata "kebudayaan" diartikan sebagai sebuah kata benda, kini lebih sebagai sebuah kata kerja. Selain itu, pengertian kebudayaan juga termasuk tradisi, dan tradisi dapat diterjemahkan dengan pewarisan atau penerusan norma-norma, adat istiadat, kaidahkaidah, harta-harta. Tetapi tradisi tersebut bukanlah sesuatu yang tak dapat diubah; tradisi justru diperpadukan dengan aneka ragam perbuatan manusia dan diangkat dalam keseluruhannya. Manusialah yang membuat sesuatu dengan tradisi itu; ia menerimanya menolaknya atau mengubahnya. Itulah sebabnya mengapa kebudayaan merupakan cerita tentang perubahan-perubahan; riwayat manusia yang selalu memberi wujud baru kepada pola-pola kebudayaan yang sudah ada (C.A. van Peursan, 1988: 11).

Berdasarkan uraian di atas dapat penulis kemukakan bahwa perkembangan pesantren, sekolah dan madrasah adalah bentuk dari kebudayaan karena terjadi dinamisasi dalam perkembangan pesantren, sekolah, dan madrasah dan sekaligus merupakan manifestasi kehidupan orang atau sekelompok orang dalam lingkungan pendidikan. Dalam memahami perkembangan pesantren, sekolah dan madrasah dalam tinjauan kebudayaan, disini menggunakan model kebudayaan yang bertahap tiga, yang dikemukakan oleh van Peursen, meliputi tahap mitologis, ontologis, dan fungsionil.

Pertama, tahap mitologis atau mitis ialah sikap manusia yang merasakan dirinya terkepung oleh kekuatan-kekuatan gaib sekitarnya, yaitu kekuasaankekuasaan dewa alam raya atau kekuasaan kesuburan seperti dipentaskan dalam 
mitologi-mitologi yang dinamakan bangsa-bangsa primitif. Kedua, tahap ontologis, ialah sikap manusia yang tidak hidup lagi dalam kepungan kekuasaan mitis, melainkan yang secara bebas ingin meneliti segala hal ikhwal. Manusia mengambil jarak terhadap segala sesuatu yang dulu dirasakan sebagai kepungan. Ia mulai menyusun suatu ajaran atau teori mengenai dasar hakekat segala sesuatu (ontologi) dan mengenai segala sesuatu menurut perinciannya (ilmu-ilmu). Ketiga, tahap fungsionil, ialah sikap dan alam pikiran yang makin nampak dalam manusia modern. Ia tidak begitu terpesona lagi oleh lingkungannya (sikap mitis), tidak lagi dengan mengambil jarak terhadap obyek penyelidikannya (sikap ontologis), melainkan ingin mengadakan relasi-relasi baru suatu kebertautan yang baru terhadap segala sesuatu dalam lingkungannya (C.A. van Peursan,1988: 18).

Auguste Comte menggunakan istilah yang berbeda dengan van Peursen di atas dalam mengenalkan tahapan kebudayaan, namun memiliki kebermaknaan yang sama. Menurut Auguste Comte, sejarah umat manusia baik secara individu maunpun secara keseluruhan, berkembang menurut tiga tahap, yaitu tahap teologi atau fiktif, tahap metafisik atau abstrak, dan tahap positif atau riil (Koento Wibisono Siswomihardjo, 1996:11).

Berdasarkan ketiga tahap kebudayaan di atas, dalam artikel ini penulis bertujuan untuk menganalisis kontekstual dalam menelusuri perkembangan pesantren, sekolah, dan madrasah di Indonesia dalam tinjauan kebudayaan.

\section{Konsep Kebudayaan dan Perkembanganya}

Kata kebudayaan berasal dari kata Sansekerta "buddhayah", yaitu bentuk jamak dari "buddh" $i$ yang berarti budi atau akal. Dengan demikian secara sederhana kebudayaan dapat diartikan hal-hal yang bersangkutan dengan akal. Kebudayaan adalah keseluruhan sistem gagasan, tindakan, dan hasil karya manusia dalam rangka kehidupan masyarakat yang dijadikan milik diri manusia dengan cara belajar (Koentjaraningrat, 2002:180). C.A. van Peursen mengatakan bahwa dewasa ini kebudayaan diartikan sebagai manifestasi kehidupan setiap orang dan kehidupan setiap kelompok orang berlainan dengan hewan, maka manusia tidak dapat hidup begitu saja di tengah alam (C.A. van Peursen, 1988:10). Oleh karena itu, untuk dapat 
hidup manusia harus mengubah segala sesuatu yang telah disediakan oleh alam. Misalnya, adanya beras agar dapat dikonsumsi harus diubah dulu menjadi nasi.

Guna lebih memahami konsep kebudayaan, berikut ini dikutip beberapa definisi kebudayaan sebagaimana dikutip oleh Supartono Widyosiswoyo (1996: 3334) antara lain:

1. Menurut Ki Hadjar Dewantara, Kebudayaan berarti buah budi manusia yaitu hasil perjuangan manusia terhadap dua pengaruh kuat, yakni alam dan zaman (kodrat dan masyarakat) yang merupakan bukti kejayaan hidup manusia untuk mengatasi berbagai tantangan dalam hidup dan penghidupannya, guna mencapai keselamatan dan kebahagiaan yang pada lahirnya bersifat tertib dan damai.

2. Menurut Sutan Takdir Alisyahbana, mengatakan bahwa kebudayaan adalah manifestasi dari cara berpikir sehingga menurutnya pola kebudayaan itu sangat luas, sebab semua perilaku dan perbuatan tercakup di dalamnya dan dapat diungkapkan pada basis dan cara berpikir termasuk di dalamnya perasaan, karena perasaan juga merupakan maksud dari pikiran.

Masih banyak definisi yang bisa kita dapatkan, namun demikian dengan adanya istilah kebudayaan dan beberapa definisi diatas, maka dapat disimpulkan bahwa kebudayaan adalah milik manusia yang hidup bermasyarakat dan didapatkan melalui proses belajar. Secara umum juga dapat disimpulkan bahwa kebudayaan mempunyai ciri-ciri antara lain: a) kebudayaan diperoleh manusia sebagai anggota masyarakat; b) kebudayaan diwariskan dari generasi ke generasi secara non genetis, tetapi diperoleh manusia melalui proses belajar; c) kebendaan kebudayaan dapat berupa gagasan, tindakan, dan hasil karya yang berbentuk material; d) kebudayaan sifatnya dinamis; dan e) kebudayaan dibutuhkan oleh manusia untuk menyesuaikan diri dengan lingkungan dan untuk memenuhi berbagai kebutuhan.

Auguste Comte (Koento Wibisono Siswomihardjo, 1996: 11) berpendapat bahwa masyarakat mengalami tiga tahap perkembangan kebudayaan, yaitu: Pertama tahap teologis. Tahap ini dimulai sebelum tahun 1300 dan menjadi ciri dunia. Tahap ini meyakini bahwa segala sesuatu yang terjadi di dunia ini dikendalikan oleh kekuatan supranatural yang dimiliki oleh para dewa, roh atau tuhan. Pemikiran ini menjadi dasar yang mutlak untuk menjelaskan segala fenomena yang terjadi di 
sekitar manusia, sehingga terkesan irasional. Dalam tahap teologis ini terdapat tiga kepercayaan yang dianut masyarakat, yaitu pertama fetisysme dan dinamise, menganggap alam semesta ini mempunyai jiwa. Contohnya, bergemuruhnya guntur disebabkan raksasa yang sedang berperang dan lain-lain. Kemudian ada animisme yang mempercayai dunia sebagai kediaman roh-roh atau bangsa halus. Kedua politeisme, sedikit lebih maju dari pada kepercayaan sebelumnya. Politeisme mengelompokkan semua dan kejadian alam berdasarkan kesamaan-kesamaan di antara mereka. Sehingga politeisme menyederhanakan alam semesta yang beranekaragam. Contoh dari politeisme, dulu disetiap sawah di desa berbeda mempunyai dewa yang berbeda. Politeisme menganggap setiap sawah dimanapun tempatnya mempunyai dewa yang sama, orang jawa mengatakan dewa padi yaitu yaitu dewi sri. Ketiga, monoteisme yaitu kepercayaan yang menganggap hanya ada satu tuhan.

Terdapat dua ciri berpikir berdasar mitos; pertama, menghindar dengan menggunakan symbol, seperti upacara ruwatan, sesaji, atau patung. Kedua, menghindari yang kongkrit menuju kepada yang abstrak, suatu abstraksi. Periode mitos sudah berakhir pada permulaan abad ke-20. Namun, mitos-mitos masih bertahan sepanjang abad ke-20, bahkan sampai pada awal abad ke-21 (Kuntowijoyo, 2002: 94).

Kedua, tahap metafisik. Pada tahap ini manusia mengalami pergeseran cara berpikir. Tahap teologis, semua fenomena yang terjadi di sekitar manusia sebagai akibat dari kehendak roh, dewa atau tuhan. Namun pada tahap ini, muncul konsepkonsep abstrak atau kekuatan abstrak selain tuhan seperti "alam". Tahap ini terjadi antara tahun 1300 sampai 1800.

Tanda dari masuknya umat ke periode ideologi ialah berdirinya sarekat Islam. Periode ini ditandai dengan cara berpikir rasional (rasional nilai, wertrational) tetapi masih non-logis berbentuk pengetahuan apriori tentang nilai-nilai abstrak, lokasi kota, perkumpulan bersifat nasional, ekonomi komersial dan industri kecil, masyarakat pedagang dan solidaritas organis, dan kepemimpinan intelektual. Maka tidak heran apabila pada masa ini organisasi politik yang baru ialah cara berpikir 
rasional namun masih tetap dengan budaya non-logis. Pada masa ini usaha yang terpenting ialah mobilisasi massa (Kuntowijoyo, 1997: 68- 69).

Ketiga, tahap positivisme. Pada tahap ini semua gejala alam atau fenomena yang terjadi dapat dijelaskan secara ilmiah berdasarkan peninjauan, pengujian dan dapat dibuktikan secara empiris. Lembaga agama yang dulunya mengatur segalanya pada tahap ini harus menyerahkan hegemoninya kepada lembaga-lembaga lainnya sehingga muncullah lembaga-lembaga lainnya. Selainnya itu muncul sekulerisme atau pemisahan dibidang agama dengan bidang yang lain. Tahap ini menjadikan ilmu pengetahuan berkembang dan segala sesuatu menjadi lebih rasional, sehingga tercipta dunia yang lebih baik karena orang cenderung berhenti melakukan pencarian sebab mutlak (tuhan atau alam) dan lebih berkonsentrasi pada penelitian terhadap dunia sosial dan fisik dalam upayanya menemukan hukum yang mengaturnya.

Dalam teori kebudayaan van Peursen (1988:18), perkembangan budaya manusia dibagi menjadi tiga tahap, yaitu mitis, ontologis, dan fungsionalis. Pertama tahap Mitis. Manusia menganggap bahwa dirinya adalah bagian dari alam. Manusia merasa bahwa dirinya berada di dalam dan dipengaruhi oleh alam. Hal ini dapat dilihat budaya Indian. Mereka sering menganggap bahwa diri mereka adalah penjelmaan dari hewan di sekitarnya. Pada tahap ini, manusia kerap memberikan kurban atau sesaji sebagai bentuk penghormatannya kepada alam. Manusia juga membuat norma-norma perlakuan terhadap alam. Sehingga hidupnya selalu selaras dengan alam dan dilindungi oleh alam itu sendiri. Dalam pandangan Kuntowijaya (1993:49) umat Islam memiliki suatu kesadaran yang disebut sebagai kesadaran mistik-religius. Kesadaran ini tergambar dalam perlawanannya terhadap kekuatan kolonial dengan diperkuat oleh ideologi yang bersifat utopia. Disebut utopia, karena umat Islam tidak merumuskan pikiran pikirannya berdasarkan aktualitas sejarah, melainkan berdasarlan kepada berbagai mitos, pandangan-pandangan mistik mengenai masyarakat yang dapat dirumusakan misalnya dalam cita-cita Ratu Adil.

Kedua, tahap Ontologis. Manusia mulai mengenal agama. Manusia tidak lagi memberikan kurban dan memandang bahwa alam merupakan sama-sama makhluk Tuhan yang harus dijaga kelestariannya. Meskipun begitu, manusia sudah mulai menjadikan alam sebagai objek yang bisa dipergunakan untuk 
mempertahankan hidupnya. Dalam alam pikiran ontologis manusia mjlai mengambil jarak terhadap segala sesuatu yang mengitarinya. Pada periode ini kesadaran umat Islam mulai berubah. Jika sebelumnya umat Islam mempunyai kesadaran mistis dan utopia, kini umat Islam mulai mencoba merumuskan ideologi. (Miftahudin, dkk, 2014).

Ketiga, tahap Fungsionalis. Manusia sudah jauh dari alam. Bahkan, alam tidak hanya sekedar dijadikan objek, tetapi telah menjadi alat untuk memenuhi kebutuhan manusia agar hidupnya nyaman. Tahap ini ditandai dengan revolusi industri di dunia dan manusia memperlakukan alam dengan mengeksplorasinya secara berlebihan. Tahap fungsionil, ialah sikap dan alam pikiran yang makin nampak dalam manusia modern. Ia tidak begitu terpesona lagi oleh lingkungannya (sikap mitis), tidak lagi dengan mengambil jarak terhadap obyek penyelidikannya (sikap ontologis), melainkan ingin mengadakan relasi-relasi baru suatu kebertautan yang baru terhadap segala sesuatu dalam lingkungannya.

Berdasarkan ketiga perkembangan kebudayaan di atas secara substansial terdapat perbedaan antara pandangan Auguste Comte dan van Peursen maupun dalam pandangan Kuntowijoyo. Bagi van Peursen, persoalannya tidak berkisar pada perkembangan yang mempunyai makna sebagai suatu gerak peningkatan ke tahap yang lebih tinggi, melainkan lebih diarahkan pada suatu strategi kebudayaan yang lebih luas. Suatu tahap memang menggantikan tahap sebelumnya namun sesuatu tahap tidak dapat dianggap lebih tinggi atau lebih baik darip ada tahap sebelumnya yang telah digantikan itu. Ini mengandung arti bahwa kesadaran religi, metafisik, dan sejenisnya pada tahap-tahap tertentu ditinggalkan oleh manusia, dan juga tidak berarti bahwa kesadaran religi, metafisik, dan sejenisnya pada tahap-tahap tertentu ditinggalkan oleh manusia, dan juga tidak berarti bahwa bertindak secara teknis atau berpikir secara logis hanya terdapat pada tahap-tahap yang dinyatakan lebih tinggi. Dalam skema yang dikemukakan oleh van Peursen ditekankan bahwa lahirnya suatu tahap dimaksudkan untuk meniadakan segi-segi negatif tahap sebelumnya. Bukan suatu utopi yang idealistik atau positivistik yang hendak disajikan oleh skema van Peursen itu, melainkan untuk mewujudkan kenyataan akan adanya konflik-konflik, 
ketegangan-ketegangan dalam setiap tahap perkembangan masyarakat (Koento Wibisono Siswomihardjo, 1996: 20).

\section{Metode Penelitian}

Penelitian ini merupakan studi analisis pemikiran yang bersumber dari berbagai literatur mengenai kemunculan pesantren, sekolah, dan madrasah di Indonesia berdasarkan perkembangan kebudayaan dalam pandangan Auguste Comte, van Peursen, dan Kuntowijoyo. Cara kerja penelitian literatur yaitu dengan memanfaatkan sumber perpustakaan untuk memperoleh data penelitian dan membatasi kegiatan hanya pada bahan-bahan koleksi pustaka saja tanpa memerlukan riset lapangan. Dengan demikian, penelitian ini merupakan serangkaian kegiatan yang berkenaan dengan metode pengumpulan data pustaka, membaca, dan mencatat serta mengolah bahan penelitian.

\section{Hasil Penelitian}

Penelitian ini menghasilkan gambaran mengenai berbagai peristiwa ataupun proses mengenai kemunculan lembaga-lembaga pendidikan di Indonesia, yaitu antara lain:

\section{Kemunculan Pesantren Di Indonesia}

Pada awalnya, pesantren merupakan institusi pendidikan paling sederhana, seluruhnya dipusatkan pada al-Qur'an dan disebut pengajian al-Qur'an. Pada dasarnya pendidikan ini berupa pelajaran membaca beberapa bagian dari al-Qur'an, dan selanjutnya diajarkan pula peraturan dan tata tertib sholat, wudlu, dan beberapa doa. Selain itu ada juga yang mengajarkan ilmu tajwid sebagai landasan untuk membaca al-Qur'an dengan baik (Karel A. Steenbrink, 1994: 10). Pola pengajaran al-Qur'an ini diberikan secara individual, baik di rumah guru, langgar, atau surau, maupun didilaksanakan di rumah orang tua murid terutama yang mempunyai kedudukan penting. Dalam pengajian ini lebih ditekankan aspek ibadah, sedangkan aspek sosial dan moral kurang diperhatikan.

Pada tahap selanjutnya berkembang pada pengajian kitab, hanya diikuti oleh santri yang sudah memiliki kualifikasi tertentu. Sistem pendidikan dalam pengajian 
kitab berbeda dengan pengajian al-qur'an sebelumnya. Para murid pengajian kitab pada umumnya masuk asrama, materi pelajaran yang diberikan lebih banyak dari pengajian al-qur'an dan pendidikan diberikan tidak hanya secara individual tetapi juga secara berkelompok (Karel A. Steenbrink, 1994: 12).

Pada tingkat pertama pengajian kitab adalah mempelajari bahasa Arab, dan apabila santri telah dapat menyelesaikan beberapa cabang tata bahasa Arab tersebut, barulah mulai pelajaran agama yang sebenarnya, yaitu yang pertama biasanya adalah fiqh, tauhid, dan tafsir al-Qur'an. Sesudah menyelesaikan ketiga macam pelajaran pokok tersebut, para santri dapat mengambil pelajaran sampingan seperti tasawuf, hadits, hisab atau falak (Karel A. Steenbrink, 1994:14).

Tugas pesantren pada tahap ini tidaklah mendidik santri agar menjadi pegawai atau petugas tertentu. Setelah tamat murid dapat diharapkan menjadi guru pesantren atau guru ngaji al-Qur'an, imam masjid atau penghulu, tetapi sebagian besar hanya mencari ilmu untuk bekal pribadi. Tugas pesantren ini dalam istilah Belanda yaitu priesterscholen, sekolah calon "pastor Islam". Karel A. Steenbrink, 1984:153). Dalam kehidupan sehari-hari di pesantren, keterlibatan seorang Kyai hanya mengajar membaca kitab, menjadi imam dan khatib sehalat jum'at menghibur kalau ada orang sakit yang datang kepadanya sambil mencoba menasehati dan mengobati dengan doa-doa.

Uraian di atas menunjukkan bahwa pada masa-masa awal, pesantren sudah memiliki tingkatan yang berbeda-beda. Tingkatan pesantren yang paling sederhana hanya mengajarkan cara membaca huruf Arab dan al-Qur'an. Sementara, pesantren yang agak tinggi adalah pesantren yang mengajarkan berbagai kitab fiqh, ilmu akidah, dan kadang-kadang amalan sufi, disamping tata bahasa Arab (Nahwu Sharf). Hal demikian ini bilamana dikontekstualisasikan pada tahapan kebudayaan yang dikemukakan oleh van Peursen dapat dikategorikan dalam tahapan mitis atau tahapan teologi/fiktif dalam pandangan Auguste Comte, karena tradisi intelektual pesantren masih terkungkung dalam materi dasar agama Islam atau materi yang diajarkan hanya materi keagamaan an sich. Selain itu, sifat pengajarannya yang masih dogmatis dari seorang kyai dan sikap santri yang pasif serta taqlid sehingga menimbulkan dogmatisme yang kuat. 
Kenyataan di atas menggambarkan kondisi pesantren dalam abad ke-19 yaitu banyak pesantren mempunyai "spesialisasi" di bidang tradisional seperti nahwu, sharaf, hadits, salah satu cabang fiqh dan penghafaalan atau pembacaan alQur'an. Diversifikasi dalam periode terakhir ini memang agak berbeda coraknya; beberapa pesantren yang khusus memperhatikan masalah keterampilan yang bisa dipakai di masyarakat pedesaan, mencapai kedudukan yang menonjol. Begitu antara lain pesantren pertanian Darul Falah di Ciampea, Bogor dan Pabelan di Muntilan mengembangkan pengajaran koperasi, teknologi tepat guna di bidang pertanian, pembangunan, air bersih, pertukangan yang sangat berarti serta mempunyai pengaruh dalam lingkungan yang sangat luas (Karel A. Steenbrink, 1984: xv-xvi).

Pesantren yang mengambil model Gontor ini sangat menekankan pengetahuan bahasa Inggris dan Arab. Lulusan dari pesantren ini lebih diarahkan ke pengurusan toko di kota kecil atau menjadi guru dan pegawai. Selain dari itu beberapa pesantren di dalam atau dekat kota besar telah menjadi sebuah asrama, dimana mahasiswa dari berbagai jurusan ilmu bertemu dalam lingkungan yang khas islam, seperti di pesantren As-Syafiiyah, Jakarta dan Jamsaren, Solo. Tetapi juga masih ditemukan diversifikasi atau spesialisasi yang bercorak lama, seperti pesantren Krapyak, dekat Yogyakarta, dimana menghafal al-Qur'an tetap dipentingkan (Karel A. Steenbrink, 1984: xvi). Bahkan pesantren Gontor sendiri memiliki 14 cabang pondok Modern Gontor yang tersebar di seluruh Indonesia (Dihyatun, 2015).

Perkembangan pesantren di atas bilamana dimasukan dalam tahapan kebudayaan termasuk tahap ontologis atau metafisik, karena pesantren sudah tidak saja sebagai institusi pendidikan dan keagamaan, an sich tetapi lebih dari itu berusaha mengembangkan diri pada perbuatan-perbuatan praktis, menanggapi soalsoal kemasyarakatan, terlibat dalam proses pengembangan dan pemberdayaan masyarakat dalam berbagai bidang kehidupan. Tugas kemasyarakatan pesantren tidaklah mengurangi tugas keagamaannya, karena peran tersebut merupakan penjabaran nilai-nilai hidup keagamaan bagi kemasyarakatan luas dan sekaligus merupakan pelaksanaan nilai hidup keagamaan dalam kehidupan sehari-hari. 


\section{Kemunculan Sekolah di Indonesia}

Pada masa kolonial Belanda, pesantren dipandang sebagai lembaga pendidikan yang rendah dan tidak membawa kemajuan bagi para muridnya. Menurut pemerintah Belanda, sistem pendidikan Islam sangat jelek. Tujuan pendidikan Islam menurut Belanda tidak menyentuh kehidupan dunia, metode yang dipakai tidak jelas dan juga kedudukan seorang guru tidak berbeda dengan pemimpin agama, selain itu tulisan Arab tidak sesuai dengan tulisan latin sehingga sulit dimasukan dalam perencanaan pendidikan pemerintah Belanda. Oleh karena itu, untuk menyaingi keberadaan pesantren, Belanda mendirikan sekolah yang diperuntukkan bagi sebagian bangsa Indonesia terutama bagi golongan priyayi dan pejabat kolonial, maka sejak saat itu terjadi persaingan antara pesantren dengan sekolah Belanda (Nurul Aini, 2009).

Pada dasawarsa terakhir abad ke-19 dimulailah pendidikan yang liberal. Pada masa itu, pendidikan kolonial juga diperuntukkan bagi sekelompok kecil orang Indonesia (terutama kelompok berada), sehingga semenjak 1870 itu mulai tersebar jenis pendidikan rakyat, yang berarti juga bagi umat Islam Indonesia. Meskipun begitu satu perluasan pendidikan kepedesaan bagi seluruh lapisan masyarakat baru terlaksana pada permulaan abad ke 20 ini oleh apa yang disebut "ethische politiek". Pendidikan kolonial ini sangat berbeda dengan pendidikan Islam yang tradisional, bukan saja dari segi metode, tapi lebih khusus dari segi isi dan tujuannya. Pendidikan yang dikelola oleh pemerintah kolonial ini khususnya berpusat pada pengetahuan dan keterampilan dunia yaitu pengetahuan umum. Sedangkan lembaga pendidikan Islam lebih ditekankan pada pengetahuan dan keterampilan berguna bagi penghayatan agama (Karel A. Steenbrink, 1984: 24). Tujuan pendidikan bukan lagi memupuk rasa takut akan Tuhan dan pusat studi bukan lagi kitab Injil. Pendidikan ditujukan kepada pengembangan kemampuan intelektual, nilai-nilai rasional dan sosial dan usaha mencapai tujuan-tujuan sekuler lainnya. Kurikulum sekolah rendah meliputi selain pelajaran tradisional membaca, menulis, dan berhitung, juga mata pelajaran baru seperti geografi, sejarah, dan pelajaran sekuler lainnya (S. Nasution, 2008: 9$10)$. 
Di antara sekolah pada masa kolonial Belanda seperti Sekolah Kelas Satu. Sekolah ini dikhususkan untuk anak-anak kaum bangsawan, lama belajarnya 5 tahun. Pada tahun 1907 dimasukkan bahasa Belanda sebagai mata pelajaran dan masa belajarnya pun diperpanjang menjadi 8 tahun. Pada tahun 1914, Sekolah Kelas Satu diubah menjadi HIS (Hollandsche Inlandsche School), sekolah rendah berbahasa Belanda untuk anak Indonesia dengan lama belajar 7 tahun. Tujuan dari sekolah ini untuk memenuhi kebutuhan pegawai-pegawai pemerintah, perdagangan, dan perusahaan (Haidar Putra Daulay, 2001: 38). Satu-satunya jalan keluar bagi orang Indonesia ialah agar mendapat pekerjaan di pemerintahan atau perusahaan Barat, maka karena itu sekolah terutama dipandang sebagai persiapan untuk menjadi pegawai (S. Nasution, 2008: 30).

Selain itu, ada juga Sekolah Kelas Dua. Sekolah ini pada mulanya belajar 3 tahun kemudian diperpanjang menjadi 5 tahun. Sekolah ini dirancang untuk mempersiapkan pegawai-pegawai rendah bagi kantor pemerintah dan perusahaan, dan juga berfungsi mempersiapkan guru bagi sekolah desa. Setelah Sekolah Kelas Satu diganti menjadi HIS, maka nama Sekolah Kelas Dua pun sering dipakai Standard School atau Sekolah Standard (Haidar Putra Daulay, 2001: 39-40). Di samping itu, terdapat pula HCS (Hollandsche Chineesche School), yakni memberikan pendidikan Belanda yang murni pada anak-anak Cina, Sekolah ini kebanyakan dikunjungi oleh Cina-Indo yang lahir di Indonesia. Tujuan inti didirikannya sekolah ini agar orang Cina tetap loyal kepada pemerintah Belanda

Selain ketiga Sekolah tersebut, terdapat "sekolah desa" yang merupakan bentuk pendidikan dasar yang terdiri dari 3 tahun pelajaran. Pengajarannya diberikan dalam bahasa Indonesia. Lulusan sekolah desa ini dapat melanjutkan ke Standard School atau Vervolgschool, tetapi lulusan sekolah tersebut belum memenuhi syarat untuk masuk ke sekolah menengah. Setelah sekolah desa, semenjak tahun 1921, murid juga dapat masuk ke schakeschool yang memiliki kurikulum 5 tahun dan lulusan sekolah ini mempunyai kesempatan yang sama dengan murid lulusan HIS (Karel A. Steenbrink, 1994: 25).

Memperhatikan kemunculan dan tujuan didirikannya sekolah pemerintah Belanda sangat jelas bahwa dapat dimasukkan dalam tahapan kebudayaan fungsionil 
atau positif/riel. Hal ini didasari oleh unsur kepentingan dan kebermanfaatan sekolah-sekolah tersebut bagi pemerintah Belanda. Tujuan pendidikan bukan lagi memupuk rasa takut akan Tuhan namun pada pengembangan kemampuan intelektual, nilai-nilai rasional dan sosial dan usaha mencapai tujuan-tujuan sekuler lainnya.

Memasuki awal abad ke-20, Steenbrink menggambarkan bahwa telah terjadi kebangkitan, pembaharuan (renaissance) atau bahkan pencerahan. Bagi tokoh-tokoh pembaharu, pendidikan kiranya senantiasa sebagai aspek yang strategis untuk membentuk sikap dan pandangan keislaman masyarakat. Dari pandangan seperti inilah terwujud lembaga pendidikan Islam baru yang dinamakan madrasah. Di samping itu, kenyataan makin merakyat sekolah-sekolah sekuler kolonial Belanda dan sikap diskriminatif dari pemerintah terhadap rakyat pribumi, juga ikut mendorong lahirnya lembaga pendidikan madrasah ini. Pada awal abad ke-20 pemerintah Hindia Belanda mengeluarkan kebijakan penting yang menentukan masa depan pendidikan di nusantara ini. Kebijakan tersebut adalah Politik Etis (Etische Politiek). Inti dari kebijakan ini adalah emansipasi bangsa Indonesia secara berangsur-angsur (S. Nasution, 1987: 16). Dari sinilah kemudian lembaga-lembaga pendidikan dengan sistem Barat diperkenalkan sampai ke lapisan golongan bawah, yang sebelumnya hanya dinikmati secara eksklusif dari kelompok-kelompok terpilih menurut ukuran Belanda. Berdasarkan kenyataan ini umat Islam meresponnya dengan melakukan sintesa antara lembaga pendidikan pesantren dengan persekolahan Belanda sehingga melahirkan bentuk lembaga pendidikan Islam madrasah (Azyumardi Azra, 1999:37-38).

\section{Kemunculan Madrasah di Indonesia}

Terdapat dua hal yang melatar belakangi tumbuhnya sistem madrasah di Indonesia, pertama adalah faktor pembaharuan Islam dan kedua respon terhadap politik pendidikan Hindia Belanda. Kemunculan dan perkembangan madrasah tidak bisa dilepaskan dari gerakan pembaharuan Islam dan kemudian dikembangkan oleh organisasi-organisasi Islam baik di Jawa, Sumatera maupun Kalimantan. Oleh karena itu pendidikan dipandang sebagai aspek strategis dalam membentuk pandangan 
keislaman masyarakat. Dalam kenyataannya, pendidikan yang terlalu berorientasi pada ilmu-ilmu agama ubudiyyah, sebagaimana ditunjukkan dalam pendidikan di masjid, surau dan pesantren, pandangan keislaman masyarakat agaknya kurang memberikan perhatian kepada masalah-masalah sosial, politik, ekonomi dan budaya, untuk melakukan pembaharuan terhadap pandangan dan tindakan masyarakat itu langkah strategis yang harus ditempuh adalah memperbaharui sistem pendidikannya. Dalam konteks inilah pada awal abad 20 madrasah mumcul dan berkembang di Indonesia. Di samping itu, perkembangan madrasah di Indonesia juga merupakan respon atas kebijakan dan politik pendidikan pemerintah Hindia Belanda pada masa itu. Dalam bahasa yang lebih sederhana dapat dikatakan bahwa madrasah dalam batas-batas tertentu merupakan lembaga persekolahan ala Belanda yang diberi muatan keagamaan (Maksum,1999: 92).

Madrasah berkembang ke arah yang mirip dengan sistem sekolah yang memakai sistem klasikal. Namun berbeda karena lebih menekankan pengajaran agama. Perkembangan dari pesantren, sekolah dan madrasah di atas, terdapat perbedaan antara pesantren dan madrasah. Pesantren dengan sistem sorogan dan halaqah menganut sistem individual, tetapi madrasah memakai sistem klasikal. Di samping itu materi yang diajarkan di madrasah tidak hanya sebatas ilmu agama, tetapi juga ilmu pengetahuan umum. Tampaknya, penggunaan istilah "madrasah" di Indonesia adalah untuk membedakan antara lembaga pendidikan Islam modern dengan lembaga pendidikan Islam tradisional dan sistem pendidikan Belanda yang sekular, sehingga sistem dan isi madrasah diupayakan adanya penggabungan antara sistem pesantren dan sekolah umum.

Berdasarkan deskripsi latar belakang kemunculan dan perkembangan madrasah bahwa pada tahap ini kemunculan dan perkembangan madrasah masuk pada tahap fungsionil, yaitu telah terjadi pergeseran dari pola tradisional ke modern. Pergeseran sistem tradisional pendidikan Islam yang dilaksanakan di masjid, langgar, dan pesantren yang tanpa batas waktu dan bebas untuk segala usia menuju sistem klasikal, penjenjangan, menggunakan fasilitas bangku/papan tulis, bahkan memulai memasukkan pengetahuan umum dalam kurikulumnya. 
Seiring dengan perjalanan waktu, dalam rangka konvergensi, Departemen Agama mengajurkan supaya pesantren yang tradisional dikembangkan menjadi sebuah madrasah, disusun secara klasikal, dengan memakai kurikulum yang tetap dan memasukkan mata pelajaran umum di samping agama (Karel A. Steenbrink, 1994, 97). Perkembangan berikutnya pesantren kemudian mengadopsi jenis pendidikan sekolah dan madrasah. Bahkan hingga kini sudah banyak pesantren yang mendirikan perguruan tinggi. Pada tahap perkembangan ini, pesantren masuk pada tahap kebudayaan fungsionil, yang berbeda dengan tahap sebelumnya mitis dan ontologis, dengan adanya indikasi keterbukaan modernisasi di tubuh pesantren untuk mengadopsi sistem madrasah dan sekolah.

\section{Kesimpulan}

Menelusuri perkembangan pesantren, sekolah dan madrasah semakin membuktikan bahwa telah terjadi dinamisasi dalam lembaga pendidikan. Proses dinamisasi ini akan terus berkembang seiring dengan perubahan dan tuntutan zaman. Pada awalnya dinamika perkembagan dalam dunia pesantren, berada dalam tahapan mitis atau teologi/fiktif, karena tradisi intelektual pesantren masih terkungkung dalam materi dasar agama Islam atau materi yang diajarkan hanya materi keagamaan an sich, kemudian bergeser pada tahap ontologi atau metafisik/abstrak, karena pada tahap ini pesantren sudah tidak saja sebagai institusi pendidikan dan keagamaan, an sich tetapi lebih dari itu berusaha mengembangkan diri pada perbuatan-perbuatan praktis, menanggapi soal-soal kemasyarakatan, terlibat dalam proses pengembangan dan pemberdayaan masyarakat dalam berbagai bidang kehidupan, dan pada perkembangan selanjutnya, bergeser pada tahap fungsionil, karena telah terjadi pergeseran di pesantren dari sistem tradisional ke moderm, atau keterbukaan modernisasi di tubuh pesantren untuk mengadopsi sistem madrasah dan sekolah.

Tahapan kebudayaan dilihat dari kemunculan sekolah dan madrasah menunjukkan bahwa kedua lembaga tersebut masuk pada tahapan fungsionil atau positif/riel. Namun demikian, sangat memungkinkan masih terdapat indikasi-indikasi budaya mitis dan ontologis di madrasah dan sekolah, karena menurut Auguste Comte 
bahwa sesuatu tahapan tidak dapat bebas sama sekali dari pengaruh tahap yang sebelumnya.

\section{Daftar Pustaka}

Azyumardi Azra, Pendidikan Islam: Tradisi dan Modernisasi Menuju Milenium Baru, Jakarta: Logos Wacana Ilmu, 1999

C.A. van Peursan, Strategi Kebudayaan, Yogyakarta: Kanisius, 1988

Masqon, Dihyatun. Buku Profil Pondok Modern Gontor. Ponorogo: Gontor Press. 2015

Haidar Putra Daulay, Historitas dan Eksistensi Pesantren Sekolah dan Madrasah, Yogyakarta: Tiara Wacana, 2001

Koentjaraningrat, Pengantar Ilmu Antropologi, Jakarta: Rineka Cipta, 2002

Koento Wibisono Siswomihardjo, Arti Perkembangan Menurut Filsafat Positivisme Auguste Comte, Yogyakarta: Gadjah Mada University Press, 1996

Kuntowijoyo, Identitas Politik Umat Islam, cet. ke-2, Bandung: Mizan, 1997

, Selamat Tinggal Mitos, Selamat Datang Realitas: Esai-esai Budaya dan Politik, cet. 1, Bandung: Mizan, 2002

Karel A. Steenbrink, Pesantren Madrasah Sekolah, Jakarta: LP3ES, 1994

, Beberapa Aspek tentang Islam di Indonesia Abad Ke-19, Jakarta: Bulan Bintang, 1984

Maksum, Madrasah Sejarah dan Perkembangannya, Jakarta: Logos Wacana Ilmu, 1999

Miftahuddin, Ajat Sudrajat, dan Djumarwan (2014). Kuntowijoyo Dan Pemikirannya: Dari Sejarawan Sampai Cendekiawan. Laporan Penelitian. Program Studi Ilmu Sejarah Jurusan Pendidikan Sejarah Fakultas Ilmu Sosial Universitas Negeri Yogyakarta Tahun 2014.

Nurul Aini, Pesantren, Organisasi Modern Islam di Masa Penjajahan, Jurnal Darussalam, Volume 8 No. 1, Januari - Juni 2009

S. Nasution, Sejarah Pendidikan Indonesia, cet. ke-3 Bandung: Jemmars, 1987 
Hendro Widodo 173

Sketsa Kebudayaan Lembaga Pendidikan Islam

S. Nasution, Sejarah Pendidikan Indonesia, Jakarta: Bumi Aksara, 2008

Supartono Widyosiswoyo, Ilmu Budaya Dasar. Jakarta: Ghalia Indonesia, 1996

at.t. | Volume. 2, No. 2, Juli-Desember 2017 
174 | Hendro Widodo

Sketsa Kebudayaan Lembaga Pendidikan Islam

at.tontains | Volume. 2, No. 2, Juli-Desember 2017 